\title{
Eksistensi Metode Ummi Dalam Meningkatkan Pembelajaran Tahsin Al-Quran Di SMP IT ABATA Lombok
}

\author{
Andrian Firdaus \\ Program studi PGMI STAI Al-Amin Gersik Kediri Lombok Barat Mataram, Indonesia \\ andrianfirdaus664@gmail.com
}

\begin{abstract}
Abstrak. Metode Ummidalam Pembelajaran Tahsis banyak teknik,dan model dalam pembelajarannya karna yang paling daras kita pahami adalah sifat -sifat huruf dalam metode ummi dan tahsin quran kita harus mengetahui keluarnya huruf dari tengorokan dan bisa pelajari dengan baik oleh guru dan sisiwa, salah satunya merupakan tahsinquran. Penelitian yang kami gunakanmerupakan penelitian kualitatif. Metode pengumpulan data menggunakan metode wawancara dan dianalisis menggunakan kualitatif. Hasil penelitian menyimpulkan bahwa eksistensi metode ummi dalam meningkatkan pembelajaran tahsin alquran di SMPIT ABATA LOMBOK adalah sangat baik, sesuai dengan langkah-langkah metode Ummi yaitu prepare, present, dan evaluasting.
\end{abstract}

Kata Kunci: Metode Ummi, Pembelajaran Tahsin Al-Quran

\begin{abstract}
The Ummi method in Tahsin Learning has many techniques, and models in learning because the most basic thing we understand is the nature of the letters in the ummi and tahsin quran method. The research we use is a qualitative research. Methods of data collection using the interview method and analyzed using qualitative. The result of the study concluded that the existence of the ummi method in improving tahsin al-quran learning at SMP-IT ABATA LOMBOK was very good, according to the steps, namely prepare, present, and evaluate.
\end{abstract}

Keywords: Keywords: Ummi Method, Learning Tahsin Al-Quran

\section{PENDAHULUAN}

Bicara tentang pendidikan merupakan usaha sadar dan terencana yang dilakukan seorang kepada orang lain dalam rangka mewujudkan proses belajar dan pembelajaran sehingga dapat membantu menemukan jati dirinya, yaitu memiliki kekuatan spiritual keagamaan, pengendalian terhadap dirinya, kecerdasan, akhlak yang mulia dan memiliki keterampilan yang dapat berguna bagi diri sendiri, masyarakat, bangsa dan Negara. ${ }^{1}$ Pendidikan nasional tidak jauh berbeda dengan pendidikan Islam yang merupakan sebuah proses pembentukan dan perkembangan budaya manusia yang sumber dan berpedoman dari ajaran Islam sebagaimana yang termaktub dalam Al-Qur'an dan Al-Hadits. Perkembangan yang dimaksud yaitu perkembangan dalam pembentukan kepribadian berdasarkan ukuran-ukuran Islam. ${ }^{2}$

${ }^{1}$ Zuhairini, FilsafatPendidikan Islam, (Jakarta: BumiAksara, 1995), hlm. 51.

2 ZakiahDrajat, IlmuPendidikan Islam, (Jakarta: BumiAksara, 2000), hlm. 28. 
Adapun tujuan akhir dari sebuah pendidikan adalah untuk membentuk akhlak mulia dan keimanan kepada Allah berdasarkan ajaran Islam yang termaktub dalam AlQur'an dan Al-Hadits.Pendidikan tentang pendidikan al-quran tidak bisa lepas dari pendidikan Islam di nusantara, Karna pendidikan al-quran menanamkan kepada diri ayat allah atau kalam allah disebut dengan al-quran nurkarim. di Indonesia paling bayak pendidikan islam dari terkecil hingga yang terbesar. di Indonesia banyak lembaga pendidikan quran seperti TPQ (Taman pendidikan Al-Quran) dan rumah tahfis dan lain-lain, namun masih pada saat ini pendidikan alquran banyak peminat nya di kalanga masyarakat. pendidikan al-quran yang memiliki ciri khas tersendiri yaitu cara bacan huruf, memahami Gorib dan tajwid. Sekolahmenegahpertamaislamterpadu (SMPIT) Abata Lombok kota Mataram bernawung di yayasan abata lombok dimana didalamnya dikembangkan metode UMMI dalam meningkatkan bacaan Al-Quran. SMPIT Abata Lombok kota mataram.

Dengan keberadaan metode UMMI ini dapat menjadikan para siswa dan sisiwi SMPIT Abata Lombok unggul dalam membaca al-quran dari pada sekolah-sekolah lain terutama sekolah yang ada di kota mataram. Hal ini dibuktikan dari berbagai event yang diikuti oleh para siswa Abata yang sering menjuarai lomba baca tartil dan Tahfis Tingkat Provensi dan mendapat Juara 1 dan 2. ${ }^{3}$ adapun permasalahan yang ada di penelitian adalah Bagaimana Penerapan Metode Ummi Dalam Peningkatan Pembelajaran Bacan Al-Quran di SMP IT ABATA LOMBOK Apa Fator Dan Pendukung Dan Penghambat Metode Ummi Dalam Peningkatan Pembelajaran Bacan Al-Quran di SMP IT ABATA LOMBOK.

\section{METODE PENELITIAN}

Metode yang digunkan dalam penelitian ini adalah kualitatif, Metode penelitian tentang eksistensi Metode ummi dalam memningkatkan pembelajaran tahsin di SMPIT abata Lombok Kota Mataram ini dilakukan dengan menggunakan metode penelitian deskriptif-kualitatif, yang merupakan metode penelitian dengan cara

${ }^{3}$ Mubarok (Mudabir/guru ), Wawancara,, Tanggal, 12 Agustus 2021. 
melakukan pengamatan, analisis dan penggambaran suatu kejadian atau fenomena yang terjadi pada suatu objek penelitian. ${ }^{4}$

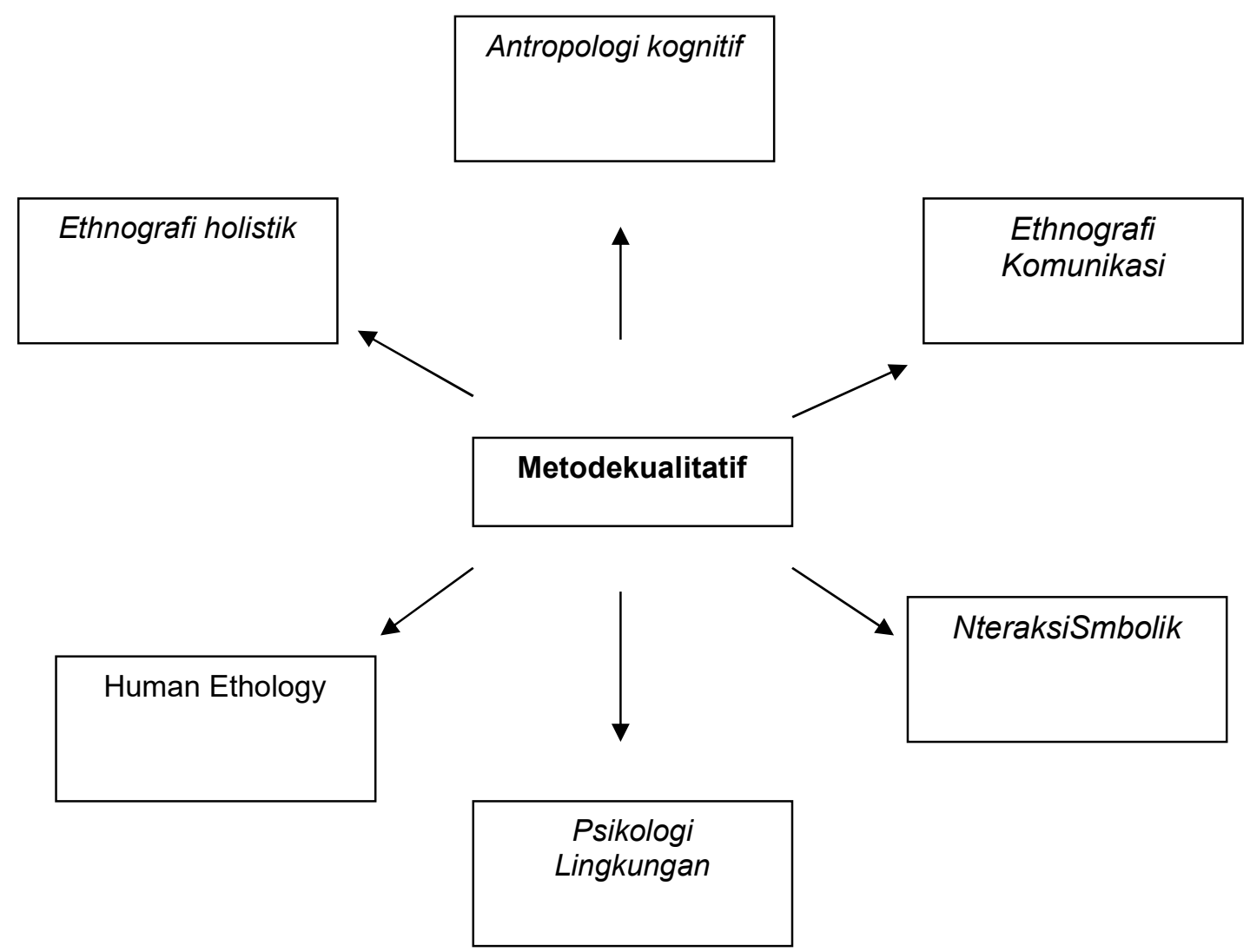

Table $1^{5}$

Peta kosep 5

\section{HASIL DAN PEMBAHASAN}

Hasil Pembelajaran tahsin di SMPIT abata Lombok bertujuan untuk meningkatkan bacaan al-quran, dengan baik dalam penarapan metode ini anak cepat memahami bacaan al-quran dengan baik dan cepat, dari sisi makharijul huruf, tajwid dan ghorib anak sudah paham dan bisa memahami dari bentuk dan sifat huruf. Oleh karna itu adanya metode ummi membantu untuk memiliki hafalan al-quran dan bacaan tahfisnya, dan keahlian dalam membaca al-quran.

4J.R.Raco, Metode Penelltlan Kualltatlf Jenis, Karakteristik ,Dan Keunggulannyai ,(Jakarta: Gramedia, 2010) Hlm.24

5 J.R.Raco, Metode Penelltlan Kualltatlf Jenis, Karakteristik, Dan Keunggulannyai ,(Jakarta: Gramedia, 2010) Hlm.24 
Pembelajaran tahsin atau al-quran dengan metode ummi utamakan ada kemauan untuk ingin bisa membaca al-quran. Namun metode ini sangat baik bagi orang yang masih belum lancar membaca alquran metode ummi ini bertujuan untuk cepat membaca dan menghafal ayat alquran.

Pembelajaran tahsin dilakukan setiap hari di SMPIT abata Lombok bagi kelas 1 sedangkan bagi kelas 2-3 tinggal menghafal kan. Maka pembelajaran tahsin dengan mengunakan metode ummi sanagt aktif dan kondusif karan, satu kali pertemuan 2 jam maka cukup waktunya penerapan tahsin mengunakan metode ummi.

Metode ini adalah Cara pendekatan yang digunakan dalam pembelajaran alquran adalah pendekatan bahsa ibu, dan pada hakikatnya pendekatan ibu itu ada 3 unsur: Direct method (metode langsung membaca cepat, Repeatation (diulang-ulang ) dan Kasih sayang yang tulus dan ikhlas.

a. Direct method (metode langsung)

Yaitu lansung dibaca tanpa dieja/diurai atau tidak banyak penjelasan.dengan kata lain learing by doing, belajar dengan melakukan secara langsung.

b. Repeatation (diulang-ulang)

Baca al-quran akan semakin kelihatan keindahan, kekuatan dan kemudahan hanya ketika mengulang-ulang ayat atau surah dalam al-quran.

c. Kasih saying yang tulus

Kekuatan cinta, kasih sayang yang tulus dan kesabaran seorang ibu dalam mendidik anak adalah kunci kesuksesanya. ${ }^{6}$

1. Keutama metode ummi

Metode ummi tidak hanya mengandalkan buku yang digunakan anakdalam belajar al-quran tetapi lebih 3 keutaman:

2. Metode yang bermutu

Terdiri dari buku pena pra untuk tk dari jilid 1-6 buku pena ummi remaja/dewasa,ghorib al-quran,tajwid dasar.

3. Guru yang bermutu

${ }^{6}$ Ummi foundation Modul guru al quran,(Surabaya: foundation pusat 2018) hlm 4-10 
Guru kopenten dalam dunia al-quran, yang sudah lulus tashih,tahsin dan sertfikasi.

1. System berbasis mutu

a. Manajemen yag baik
b. kulifikasi guru
c. Tahapan yang baik dan benar
d. Target jelas dan terukur
e. Mastery learning yang konsisten
f. Waktu memadai
g. Quality control yang intensif
h. Rasio guru dan siswa profesional
i. Progress raport setiap siswa
j. Koodinator yang handal

4. Model pembelajaran metode ummi

1. Privat/individual

Metodologi privat atau individual adalah metode pembelajaran alquran yang dijalankan dengan cara murid panggil atau di acar satu persatu semetara anak yang lain diberitugas membaca sendiri.

2. Klasikal individual

Klasikal individual adalah sebuah metode pembelajaran baca al-quran yang di jalankan dengan cara membaca bersama-sama halaman yang ditentukan oleh guru, selanjutnya setelah dianggap tuntas oleh guru, pembelajaran dilanjutkan dengan individual.

3. Klasikal baca simak

Klasikal baca simak adalah sebuah pembelajaran baca al-quran yang di jalanakan Klasikal baca simak murni dengan cara membaca bersamasama halaman yang ditentukan oleh guru, selanjutnya setelah dianggap tuntas oleh guru, pembelajaran dilanjutkan dengan pola baca simak, yaitu satu anak membaca sementara lain menyimak halaman yang dibaca oelh temannya, hal ini dilakukan walapun halaman baca simak anak yang satu berbeda dengan halaman baca anak yang lain. 
4. Klasikal baca simak murni

Metode baca simak murni sama dengan metode klasik baca simak, perbedaanya kalu klasikal baca simak murni jilid dan halaman anak dalam satu kelompok sama.

Sedangkan dari factor pendukung sarana dan prasarana sekolah memadai dan semua pihak mendukung dengan adanya metode ummi untuk meningkatkat kualitas dan kuantitas guru dalam pembisaan membaca al-Quran sedang factor penghabat minta siswa sangat mimi dan pengaruhi oleh zaman.

\section{KESIMPULAN}

Eksistensi Metode Ummi Dalam Meningkatkan PembelajaranTahsin Al-Quran Di SMP IT Abata Lombok di Kota Mataram Nusa Tenggara Barat telah banyak perubahan dari segi bacaan,tajwid dan sifat huruf dalam al-quaran. Metode Ummi dan Pembelajaran Tahsin Al-Quran sangat membantuk mengubah bacaan dan meningkatkan hafalan anak dan hasil yang baik, sesuai dengan langkah-langkah pembelajarannya prepare, present, dan evaluasting.

\section{SARAN}

Diharapkan metode ini terus berkembang dalam meningkatkan baca anak maupun orang dewasa karna masih banyak di luar sana masih kurang bacaannya sehingga lupa cara membaca al-quran terutama sifat huruf,dan tajwid dalam membaca AlQur'an.

\section{DAFTAR PUSTAKA}

Zuhairini, FilsafatPendidikan Islam, Jakarta: BumiAksara, 1995

ZakiahDrajat, IlmuPendidikan Islam, Jakarta: BumiAksara, 2000

J.R.Raco, METODE Penelltlan Kualltatlf JENIS, Karakteristik,Dan Keunggulannyai Jakarta:Gramedia, Jakarta, 2010

Ummi foundation Modul guru Al-Qur'an, Surabaya: foundation pusat 2018 